\title{
Survival and growth rates of juvenile salmonids reared in lowland streams
}

\author{
Janusz Golski, Jan Mazurkiewicz, Wojciech Andrzejewski, Antoni Przybył, Jerzy Kozak
}

Received - 15 July 2016/Accepted - 26 October 2016. Published online: 31 December 2016; OInland Fisheries Institute in Olsztyn, Poland Citation: Golski J., Mazurkiewicz J., Andrzejewski W., Przybył A., Kozak J. 2016 - Survival and growth rates of juvenile salmonids reared in lowland streams - Arch. Pol. Fish. 24: 187-200.

\begin{abstract}
The aim of this study was to assess the efficiency of propagating juvenile trout, Salmo trutta L. in small lowland streams and to evaluate the impact of the environmental conditions in the streams on the juvenile fish. Brown trout (Salmo trutta fario) and sea trout (Salmo trutta trutta) early fry fed under controlled conditions were used to stock third-order lowland streams. During summer, fall, and spring catches, fry were counted, measured, and weighed. The following parameters were calculated using the data collected: fry stocking density (ind. $\mathrm{m}^{-2}$ ); survival; specific mortality rate (SMR); length range; mean specimen length; body weight; mean body weight; specific growth rate (SGR); body condition (Fulton's index). The ichthyological studies were accompanied by simultaneous analyses of environmental conditions that were performed monthly, and benthic macroinvertebrates were sampled in spring and fall. No differences were observed in the biological parameters analyzed between sea trout and brown trout. Variability in environmental parameters such as temperature, oxygenation, conductivity, and stream width and depth were associated with differentiation in the biological parameters of the fry. The results clearly indicate that the considerable potential of small
\end{abstract}

\footnotetext{
J. Golski [ ڤ'], J. Mazurkiewicz, W. Andrzejewski, A. Przybył Department of Inland Fisheries and Aquaculture Institute of Zoology Poznań University of Life Sciences

Wojska Polskiego 71 C, 60-625 Poznań, Poland

e-mail: golski@up.poznan.pl, tel. +48 618487723

J. Kozak

Natural History Collections, Faculty of Biology

Adam Mickiewicz University

ul. Umultowska 89, 61-614 Poznań, Poland
}

lowland streams for the propagation of salmonid juvenile stages is currently underexploited.

Keywords: fry survival, juvenile salmonids, lowland streams, stocking, brown trout, sea trout

\section{Introduction}

Since the 1970s, ichthyologists have focused research efforts on the rapid decline in salmonid populations caused by water pollution, civil engineering structures, river channel regulation, and overfishing (Przybył 1976, Sych and Bartel 1979, Bartel 1987, 2001, Czerniawski et al. 2010a, Augustyn 2011). These anthropogenic factors contributed to the extinction of the Atlantic salmon, Salmo salar L. and drastic reductions in populations of sea trout, Salmo trutta trutta L., brown trout, Salmo trutta fario L., and grayling Thymallus thymallus (L.) to the extent that, at certain periods, the occurrence of these species was dependent wholly on stocking operations.

Brown and Day (2002) predict that the protection of valuable salmonids will depend on stocking with material propagated under controlled conditions at hatcheries. However, many authors contend that stocking programs are of limited effectiveness, and, increasingly, there is widespread doubt as to whether fry produced under controlled conditions

(c) Copyright by Stanisław Sakowicz Inland Fisheries Institute in Olsztyn.

(C) 2016 Author(s). This is an open access article licensed under the Creative Commons Attribution-NonCommercial-NoDerivs License (http://creativecommons.org/licenses/by-nc-nd/3.0/). 
can form stable wild populations (Chełkowski et al. 1990, Berejikian et al. 2000, Jonsson 2001, Bębnowska et al. 2005, Borsuk et. al. 2006, Brockmark and Johnsson 2010, Czerniawski et al. 2011, 2015). To date, stocking success has been assessed by the number of fry released rather than fry survival and recovery as spawners; however, the survival of hatchery-origin stocking material is at least twofold lower than that of wild fish, and this can only be compensated for by the quantity of fry released (Jonsson 2001, Brown and Day 2002, Teixeira et al. 2006, Augustyn 2011).

Failure of stocking efforts results from domestication, i.e., the loss of natural instincts in fish that are reared under controlled conditions, and releasing stocking material into inappropriate habitats at inappropriate times (Berejikian et al. 2000, Jonsson 2001, Bębnowska et al. 2005, Brockmark and Johnsson 2010, Czerniawski et al. 2010a, 2010b, Augustyn 2011). Berejikian et al. (2000) reports that changes in the competitive behavior of fry occur as soon as 49 to 78 days of rearing under artificial conditions.

In view of the confirmed unsatisfactory efficiency of current stocking operations, the need to develop new fry propagation methods based on the latest research is urgent. These methods must ensure that fry retain the natural behaviors that allow them to survive in the natural environment. The principle research areas into salmonid reintroduction include accelerated incubation and rearing at warmer water temperatures (Trzebiatowski and Domagała 1992a), rearing using natural food (Bębnowska et al. 2005, Czerniawski et al. 2007, 2009a, 2009b, 2010a, 2012, 2015), training fry prior to stocking (Brown and Day 2002, Bębnowska et al. 2005, Czerniawski et. al. 2010b), and rearing under natural conditions in small streams with excellent food conditions (Chełkowski et al. 1990, Trzebiatowski and Domagała 1992b, Augustyn et al. 2006, Höjesjö et al. 2014, Louison and Stelzer 2016). Although decades ago Kaj (1946) and Iwaszkiewicz (1965) proposed rearing brown trout fry in small streams in central Poland, to date little attention has been focused on the environmental conditions in streams that could potentially be used for rearing fry or on the effects of physicochemical parameters on fry survival and growth. Thus, no alternative stocking material propagation method to conventional rearing under controlled conditions has been developed. The objective of this study was to assess the efficiency of rearing sea trout and brown trout juvenile stages in small lowland streams that are not yet exploited by fisheries. The impacts of different environmental parameters on fry survival and growth were also assessed.

\section{Materials and methods}

Following the resorption of two-thirds of the yolk sac, brown trout and sea trout alevin were fed ad libitum with live zooplankton (Daphnidae) and artificial feed at a 1:1 ratio. In the last week, the food was supplemented with small amounts of chironomid larvae (Chironomidae). Rearing was conducted in long stream tanks at the experimental facility of the Department of Inland Fisheries and Aquaculture, Poznań University of Life Sciences. After four weeks of rearing under controlled conditions, the fry were stocked into seven tributaries of the middle Warta River in the section between the towns of Oborniki and Międzychód. The names of the tributaries, the abbreviations used in this paper, the forms of trout, geographical coordinates, and the lengths of the research sections are provided in Table 1 . The streams were selected for stocking based on the results of earlier preliminary studies. All of the streams are small primary tributaries of the Warta characterized by a very small catchment area, a maximum width of 5 $\mathrm{m}$, and low productivity. Only two streams (Smolnica, Kamionka) are longer than $10 \mathrm{~km}$, and adequate conditions for this experiment were only found in short sections of them. The three retention reservoirs on the Smolnica have caused habitat degradation along most of the stream, and the last section in which semi-natural conditions are preserved is only $2 \mathrm{~km}$ long.

The Bąblinek, Kiszewo, and Chojno-Błota streams have the smallest mean width of a maximum 
Table 1

Description of research area

\begin{tabular}{|c|c|c|c|c|}
\hline \multirow[b]{2}{*}{ Stream } & \multirow[b]{2}{*}{ Form of trout } & \multicolumn{2}{|c|}{ Geographical coordinates } & \multirow[b]{2}{*}{ The length of research section (m) } \\
\hline & & Latitude N & Longitude E & \\
\hline Bąblinek (B) & Brown trout & 52.681200 & 16.691536 & 500 \\
\hline Kiszewo (KS) & Brown trout & 52.678673 & 16.676677 & 700 \\
\hline Smolnica (SM) & Brown trout & 52.748149 & 16.433486 & 2000 \\
\hline M. Smolnica (MS) & Sea trout & 52.724810 & 16.421470 & 900 \\
\hline Chojno-Błota (CB) & Sea trout & 52.713066 & 16.242536 & 700 \\
\hline Chojno-M (CM) & Sea trout & 52.685394 & 16.159601 & 900 \\
\hline Kamionka (KM) & Sea trout & 52.544667 & 15.972404 & 2000 \\
\hline
\end{tabular}

of $2 \mathrm{~m}$, while the mean width of the other streams is over $3 \mathrm{~m}$ (Table 2). The deepest streams are the Smolnica and Kamionka, while the shallowest are the Bąblinek, Chojno-Błota, and Mała Smolnica. The greatest channel morphometry variability expressed as the coefficient of depth variation is in the Kamionka and Chojno-Błota, while the lowest is in the Kiszewo and Mała Smolnica. The amount of instream cover available to the fish was varied, and the most abundant was noted in the Kiszewo, Mała

Table 2

Characteristics of selected streams

\begin{tabular}{|c|c|c|c|c|c|c|c|}
\hline \multirow[b]{2}{*}{ Parameter } & \multicolumn{3}{|c|}{ Brown trout } & \multicolumn{4}{|c|}{ Sea trout } \\
\hline & $\mathrm{B}$ & KS & $\mathrm{SM}$ & $\mathrm{CB}$ & $\mathrm{CM}$ & $\mathrm{KM}$ & MS \\
\hline Stream length $(\mathrm{km})$ & 1.1 & 3.3 & 19 & 1.5 & 3.2 & 22 & 2.6 \\
\hline Catchment area $\left(\mathrm{km}^{2}\right)$ & 8 & 22 & 74 & 10 & 19 & 134 & 21 \\
\hline Average width (m) & 1.2 & 1.7 & 3.5 & 1.3 & 4.4 & 3.2 & 3.1 \\
\hline Average depth $(\mathrm{cm})$ & 8 & 22 & 26 & 11 & 17 & 31 & 12 \\
\hline Depth - coefficient of variation (\%) & 41 & 33 & 43 & 47 & 35 & 59 & 21 \\
\hline $\mathrm{W} / \mathrm{D}$ ratio* & 15 & 8 & 14 & 12 & 26 & 10 & 26 \\
\hline Share of gravel area (\%) & 2 & 3 & 25 & 0 & 20 & 30 & 50 \\
\hline Instream cover - quantity/type ${ }^{* *}$ & $2 \mathrm{~W}$ & $3 \mathrm{~V}$ & $2 \mathrm{~V} / \mathrm{W}$ & $2 \mathrm{R} / \mathrm{W}$ & $2 \mathrm{R}$ & $3 \mathrm{R} / \mathrm{V}$ & $2 \mathrm{~W}$ \\
\hline Temperature $-\min .\left({ }^{\circ} \mathrm{C}\right)$ & 6.6 & 3 & 1.2 & 4.9 & 1.4 & 1.3 & 4.6 \\
\hline Temperature - max. $\left({ }^{\circ} \mathrm{C}\right)$ & 10.1 & 16.5 & 17.8 & 15.3 & 23.3 & 17.7 & 12.2 \\
\hline Dissolved oxygen min. $\left(\mathrm{O}_{2} \mathrm{dm}^{-3}\right)$ & 5.6 & 4.8 & 5 & 5.8 & 7.2 & 6.2 & 4.7 \\
\hline Dissolved oxygen max. $\left(\mathrm{O}_{2} \mathrm{dm}^{-3}\right)$ & 9.3 & 8.8 & 8.6 & 9 & 11.3 & 11.7 & 7.3 \\
\hline Conductivity - max. $\left(\mu \mathrm{S} \mathrm{cm}^{-1}\right)$ & 262 & 270 & 312 & 273 & 256 & 560 & 220 \\
\hline Average invertebrate density (ind. $\mathrm{m}^{-2}$ ) & 3322 & 2432 & 1589 & 1621 & 839 & 996 & 2822 \\
\hline Average Gammarus sp. density (ind. $\mathrm{m}^{-2}$ ) & 3125 & 1836 & 1429 & 1161 & 667 & 751 & 2715 \\
\hline
\end{tabular}

* Average width/average depth

** $\mathrm{W}$ - woody debris; $\mathrm{V}$ - vegetation; $\mathrm{R}$ - roots 
Smolnica, and Bąblinek. The type of cover in these streams is also diverse. Woody debris predominates in the Bąblinek and Mała Smolnica, while it is provided mainly by aquatic vegetation in the Kiszewo and by tree roots in the other streams. The streams investigated are classified as one of two abiotic types: lowland sandy streams (Bąblinek, Kiszewo, Chojno-Błota, Kamionka) and lowland gravel streams (Smolnica, Chojno-Młyn, Mała Smolnica, Kamionka). The following five fish species were reported in preliminary catches before the main experiment: gudgeon, Gobio gobio (L.); three-spined stickleback, Gasterosteus aculeatus L.; ten-spined stickleback, Pungitius pungitius (L.); stone loach, Barbatula barbatula (L.); European brook lamprey, Lamperta planeri (Bloch). Because of their small population sizes, these species were not in competition with the fry; moreover, no predators were found.

During stocking, the fry were released along 100 $\mathrm{m}$ stretches in the middle of the experimental sections of the streams. Stocking density was determined for the entire length of the section. The mean length (l.t.) of the fry released ranged from 24.8 to $31.1 \mathrm{~mm}$, and the average body weight was between 0.17 and $0.33 \mathrm{~g}$. Stocking densities ranged from 0.6 to 2.2 (mean $1.4 \pm$ $0.572)$ ind. $\mathrm{m}^{-2}$. During monitoring studies in all the streams, summer fry (the beginning of July) and fall fry (mid-October) were caught, while spring fry in the second year of life (the end of March) were also caught in the Chojno-Błota, Mała Smolnica, and Kamionka. Single fish were caught with an IUP 12 Electric Pulse Fishing device in the stream section being analyzed. In the streams stocked with sea trout, catches were also made downstream from the section analyzed. After anesthetizing the specimens in a clove oil solution, they were measured (longitudo totalis, longitudo corporis) to the nearest $\mathrm{mm}$, weighed to the nearest $0.1 \mathrm{~g}$, and then released at the capture site. The fry caught in the Mała Smolnica in the spring of the second year of the study were transferred to the larger Chojno-Młyn stream.

Stocking density (ind. $\mathrm{m}^{-2}$ ) was calculated in the section of the stream into which the fry were released. Next, fry survival rates were determined based on the stocking density differences between the release and capture dates. Specific mortality rates (SMR) and specific growth rates (SGR) were calculated using formulas from Augustyn et al. 2006.

Environmental conditions were monitored monthly simultaneously with the ichthyological studies. Hydromorphological parameters, including stream width and depth, water flow rate, and bottom structure, were measured, and the amounts and types of instream cover were determined. Moreover, basic water physicochemical parameters, including $\mathrm{pH}$, temperature, dissolved oxygen content, and conductivity, were recorded. These data were used to calculate the mean widths and depths of the streams, the variation coefficients of depth measured in stream currents, the mean width to mean depth ratio, and the proportion of gravel substrate and instream cover on the bottoms of the sections analyzed. Benthic macroinvertebrates were sampled in the spring and fall to estimate the potential food base. Two samples comprising 20 subsamples each were collected from each section. The invertebrate population density (ind. $\mathrm{m}^{-2}$ ) was determined especially for the family Gammaridae.

Analyses of the data from the streams permitted comparing fry survival rates, growth rates, and Fulton condition in the different seasons with the aim of determining which streams provide the most advantageous conditions for fry and which parameters are decisive in determining this. Preliminarily, it was assumed that fry biological parameters will differ for the two forms of $S$. trutta, but, in the event there were no differences, it was decided to compare all the streams together without dividing them according to fry forms. Medians, minimums, maximums, and standard deviations were used in the statistical description of the variables. Univariate and multivariate procedures were also used in the statistical analysis. The significance of differences in a single trait among several groups was assessed using the median test. The relationship between two traits was assessed using Pearson's correlations. Calculations were performed with STATISTICA (ver. 6.0). Differences were assumed to be statistically significant at $\mathrm{P}$ $<0.05$. 


\section{Results}

\section{Environmental conditions}

Statistical analysis indicated no statistically significant differences between the two groups of streams into which the brown trout and sea trout were released, whereas when all the streams were analysed as one group, the various parameters differed significantly $(\mathrm{P}<0.05)$ (Table 3). The factor of water temperature greatly differentiated the streams investigated, and they can be divided into two groups (Fig. 1). The first includes the Bąblinek, Kiszewo, Chojno-Błota, and Mała Smolnica streams in which slight temperature fluctuations were recorded throughout the year. The water temperature in these steams did not drop below $4^{\circ} \mathrm{C}$ in winter, and they never froze, while in the summer the water temperature did not exceed $15^{\circ} \mathrm{C}$. The group comprising the Smolnica, Chojno-Młyn, and Kamionka streams is characterized by considerable fluctuations in temperature throughout the season. The lowest temperatures oscillated around $1^{\circ} \mathrm{C}$, which means that parts of the channels could freeze during very cold winters, while in the summer the maximum temperature exceeded $17^{\circ} \mathrm{C}$, and in the Chojno-Młyn it reached $23.3^{\circ} \mathrm{C}$. Dissolved oxygen concentrations in all the streams were good, with a minimum that fluctuated around $5 \mathrm{mgO}_{2} \mathrm{l}^{-1}$ recorded in the Kiszewo, Smolnica, and Mała Smolnica, while the highest minimums and maximums were noted in the Chojno-Młyn and Kamionka (Fig. 1). Electrolytic conductivity differed significantly in the streams, and the lowest values were noted in the Mała Smolnica and Chojno-Młyn streams, while the highest were recorded in the Kamionka (Fig. 1).

\section{Food base}

The benthic macrofauna diveristy in the streams analysed was low, and the predominant species was Gammarus pulex. The share of this species in the population ranged from 76 to $94 \%$. The highest mean population density (specimen $\mathrm{m}^{-2}$ ) of this species was noted in the Bąblinek (3125) and Mała Smolnica (2715). Average density was recorded in the Kiszewo (1836), Smolnica (1429), and Chojno-Błota (1161), and the lowest density was in the Chojno-Młyn (667) and Kamionka (751) (Table 2). The other macroinvertebrate groups recorded in the streams included caddis-flies (Trichoptera), common mayflies (Ephemeroptera), dipterans (Diptera), and beetles (Coleoptera). No significant differences in macroinvertebrate density were noted among the streams $(\mathrm{P}>0.05)$.

Table 3

Results of median test and descriptive values of selected environmental parameters

\begin{tabular}{lllllll} 
Parameter & $\mathrm{p}$ & $\mathrm{N}$ & Median & Minimum & Maximum & SD \\
\hline \hline Average width $(\mathrm{m})$ & 0.008 & 23 & 3.10 & 1.20 & 4.40 & 1.13 \\
Average depth $(\mathrm{m})$ & 0.008 & 23 & 0.17 & 0.08 & 0.31 & 0.081 \\
Depth variability & 0.008 & 23 & 44.00 & 21.00 & 59.00 & 12.60 \\
The share of gravel $(\%)$ & 0.008 & 23 & 20.0 & 0.0 & 50.0 & 17.84 \\
Shelters $(\%)$ & 0.008 & 23 & 40.0 & 20.0 & 80.0 & 19.04 \\
Temperature $\left({ }^{\circ} \mathrm{C}\right)$ & 0.040 & 51 & 9.4 & 1.2 & 23.3 & 4.63 \\
Dissolved oxygen $\left(\mathrm{O}_{2} \mathrm{l}^{-1}\right)$ & 0.004 & 51 & 7.55 & 4.7 & 11.7 & 1.84 \\
Conductivity $\left(\mu \mathrm{S} \mathrm{cm}^{-1}\right)$ & 0.003 & 51 & 265 & 104 & 560 & 82.33 \\
\hline \hline
\end{tabular}



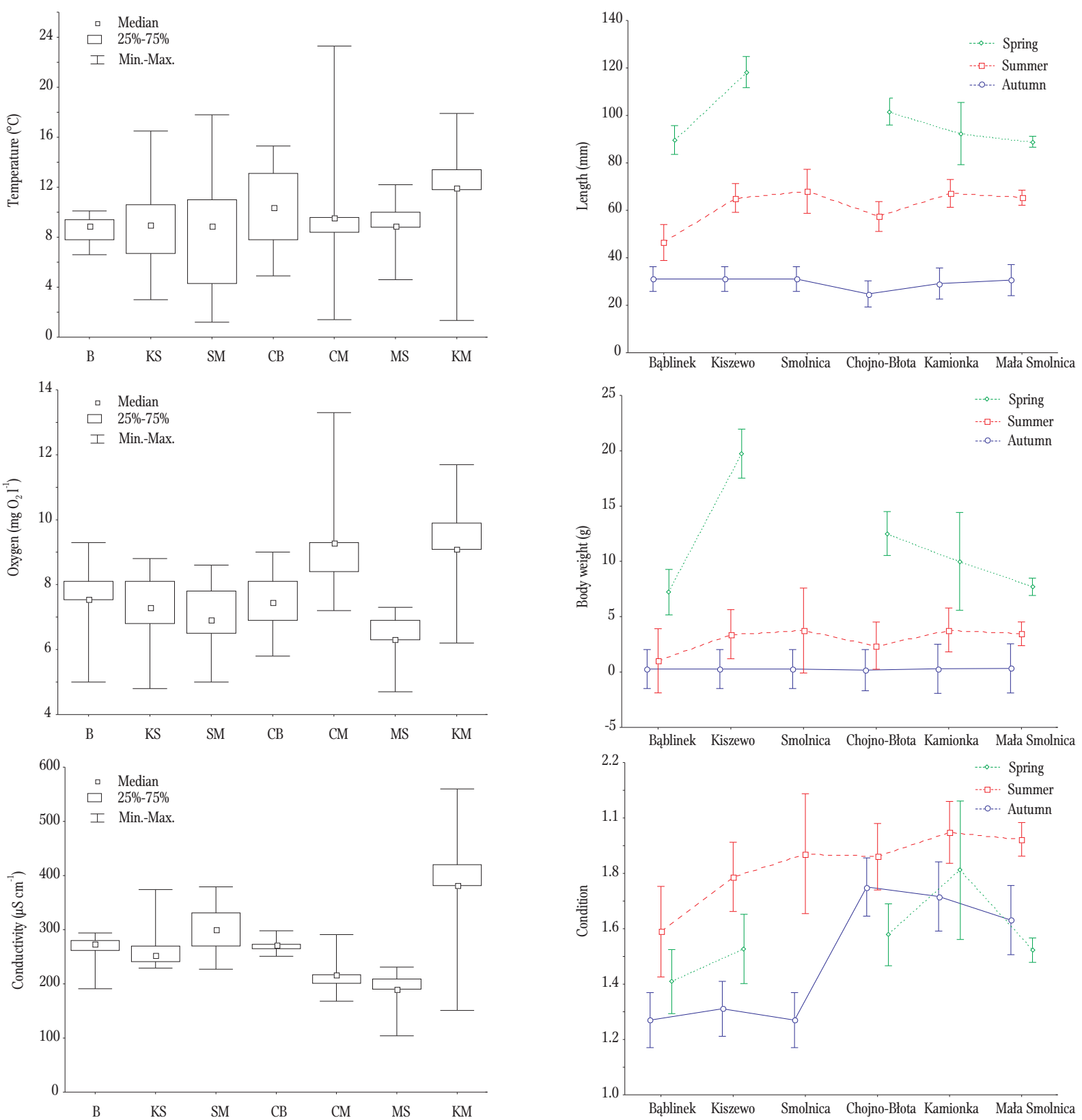

Figure 1. Physicochemical parameter variation in the streams analyzed.

Figure 2. Changes in S. trutta fry body length, weight, and condition.

which is strongly influenced by retention reservoirs.

\section{Fry survival, size, and growth rate}

Fry survival rates varied greatly with fluctuations among the streams and seasons of the year (Table 4), but no significant differences were noted between brown trout and sea trout. The lowest fry survival was recorded in spring and summer in the Smolnica, The highest survival was recorded in the Bąblinek, which is the smallest, shallowest stream. The mean survival rate for summer fry in six of the streams was $54 \%$, but when the Smolnica was excluded, this figure was $70.8 \%$. Less survival rate variation was observed in fall, while the mean value from the time of stocking was $40 \%$, excluding the Smolnica. A similar fry 
Table 4

Fry stocking density, survival, specific mortality rate (SMR), and specific growth rate (SGR)

\begin{tabular}{|c|c|c|c|c|c|}
\hline Stream & Season & Density (ind. $\mathrm{m}^{-2}$ ) & Survival (\%) & SMR (\%) & SGR (\%) \\
\hline \multirow[t]{3}{*}{ Bąblinek } & Spring* & 1.7 & 100 & & \\
\hline & Summer & 1.5 & 88.2 & 0.31 & 2.33 \\
\hline & Autumn & 0.69 & 40.6 & 1.82 & 2.45 \\
\hline \multirow[t]{3}{*}{ Kiszewo } & Spring* & 1 & 100 & & \\
\hline & Summer & 0.6 & 60 & 1.25 & 3.9 \\
\hline & Autumn & 0.4 & 40 & 0.97 & 3.1 \\
\hline \multirow[t]{2}{*}{ Smolnica } & Spring* & 0.6 & 100 & & \\
\hline & Summer & 0.018 & 3 & 8.55 & 4.03 \\
\hline \multirow[t]{4}{*}{ Chojno-Błota } & Spring* & 2.2 & 100 & & \\
\hline & Summer & 1.8 & 82 & 0.42 & 5.9 \\
\hline & Autumn & 0.93 & 43.2 & 0.80 & 1.74 \\
\hline & Spring1+ & 0.57 & 26 & 0.29 & 0.4 \\
\hline \multirow[t]{3}{*}{ Chojno-Młyn } & Spring* & 0.19 & 100 & & \\
\hline & Summer & 0.15 & 79 & 0.20 & 0.39 \\
\hline & Autumn & 0.09 & 47 & 0.43 & 0.26 \\
\hline \multirow[t]{4}{*}{ Kamionka } & Spring* & 1.9 & 100 & & \\
\hline & Summer & 1.5 & 79 & 0.39 & 4.29 \\
\hline & Autumn & 0.46 & 24 & 1.71 & 0.9 \\
\hline & Spring1+ & 0.18 & 9.5 & 0.39 & 0.7 \\
\hline \multirow[t]{4}{*}{ M. Smolnica } & Spring* & 1.2 & 100 & & \\
\hline & Summer & 0.58 & 48 & 0.91 & 2.96 \\
\hline & Autumn & 0.45 & 38 & 0.30 & 0.94 \\
\hline & Spring1+ & 0.34 & 28 & 0.16 & 0.38 \\
\hline
\end{tabular}

*initial values of density and survival at release

survival rate from stocking until the fall of $40 \%$ was recorded in the Bąblinek, Kiszewo, Chojno-Błota, and Mała Smolnica. A considerable increase in daily mortality (SMR) was noted in the Bąblinek in summer, and the highest mortality was noted there and in the Kamionka. In the summer, the mean daily mortality for five streams (excluding the Smolnica) was two-fold higher than during the spring. The lowest periodic mortality was noted in the Mała Smolnica, and it is the only instance of a considerable decrease in this index in the summer.

In three of the streams analyzed, the spring sea trout fry aged $1+$ mean was $21.7 \%$, but, because of the migratory nature of this species at this age, this figure is likely to be underestimated. In the Kamionka, the first few downstream migrating sea trout were observed in fall catches, thus the value of $10 \%$ for this index in the spring should not be considered to be the actual survival rate, but rather the minimum one. Periodic mortality in the winter was markedly lower than in the other seasons. In the Chojno-Młyn, the minimum survival rate from spring fry $1+$ to the pre-smolt stage in summer was $79 \%$, while to the smolt stage in fall it was $47 \%$. Sea trout were found only in the short section in the vicinity of the stocking site, and no specimens were found either upstream or downstream in the direction of the Warta confluence. The survival of fry that were feeding exogenously and were 
transferred from the Mała Smolnica to Chojno-Młyn to the smolt stage was approximately $20 \%$.

Similarly to survival rates, growth rates fluctuated considerably throughout the experimental period (Table 4, Fig. 2). No significant differences were noted in growth rates between the brown trout and sea trout; thus, the streams were not divided into two groups representing the fish that had been released into them prior to comparisons. The greatest increases in length and weight were noted in the summer fry from the Smolnica, Kamionka, Mała Smolnica, and Kiszewo streams, while the lowest were in summer fry from the Bablinek and Chojno-Błota streams. The greatest specific growth rate (SGR) in the summer catches was noted in fry from the Chojno-Błota and Kamionka, while the lowest values were observed in the Bąblinek. This pattern shifted in fall, with the greatest increases in fry length and body weight noted in the Kiszewo and Chojno-Błota, while the lowest were in the Mała Smolnica and Bąblinek. The highest average daily weight gain (SGR) in the summer was recorded in the Kiszewo and Bąblinek, while the lowest was in the Kamionka and Mała Smolnica. In the Bąblinek, the values of this index increased slightly in relation to the summer catch, while in the Kiszewo differences were slight, and in the other streams in the summer marked decreases were observed in the periodic growth rate.
In three of the streams analyzed, the greatest increases in spring fry $1+$ body length and weight were recorded in the Kamionka, while the lowest were noted in the Mała Smolnica. The average weight of specimens from the Kamionka was more than three times higher than in those from the Mała Smolnica. Sea trout from the Kamionka were also characterized by the highest growth rates in winter. The stocking material released into the Chojno-Błota stream had the smallest body dimensions, which led to discrepancies between the length and body weight of the summer fry and the specific growth rate in spring. During the fall catches, sea trout from the Chojno-Błota were smaller only in comparison to the specimens from the Kiszewo. The lowest body condition index values in the summer catches were noted in the fish caught in the Bąblinek, while in the other steams this parameter fluctuated at a similarly high level (Fig. 2). Sea trout body condition deteriorated in the summer in all of the streams analyzed; the highest value of this index was recorded in the Kamionka and the lowest in the Bąblinek.

\section{Correlation between environmental factors and fry survival, growth, and body condition}

Correlation coefficient analysis permitted determining the relationships between fry survival, growth,

Table 5

Correlation coefficients for environmental parameters and fry biological traits

\begin{tabular}{|c|c|c|c|c|c|c|}
\hline Parameters & Survival & SMR & $\begin{array}{l}\text { Average } \\
\text { length }\end{array}$ & $\begin{array}{l}\text { Average } \\
\text { body weight }\end{array}$ & Fulton's index & SGR \\
\hline Temperature & $-0.82^{*}$ & $0.73^{*}$ & -0.43 & -0.30 & $0.69 *$ & 0.42 \\
\hline Dissolved oxygen & -0.03 & -0.46 & $0.80 *$ & $0.72 *$ & -0.47 & -0.36 \\
\hline Conductivity & $-0.65^{*}$ & 0.36 & -0.28 & -0.20 & $0.87^{*}$ & 0.06 \\
\hline Density of Gammarus sp. & 0.35 & -0.00 & -0.36 & -0.21 & -0.43 & $0.62 *$ \\
\hline Width & $-0.53^{*}$ & 0.14 & 0.30 & 0.31 & 0.07 & -0.49 \\
\hline Depth & $-0.68^{*}$ & 0.31 & 0.08 & 0.20 & $0.78 *$ & -0.03 \\
\hline Depth variability & -0.27 & -0.06 & $0.53 *$ & $0.56 *$ & 0.43 & -0.30 \\
\hline
\end{tabular}

* - significant correlations at $\mathrm{P}<0.05$ 
and condition and environmental parameters (Table 5). Survival significantly negatively correlated with maximum temperature, conductivity, and stream width and depth. Fry body weight and length were significantly positively correlated with dissolved oxygen content, invertebrate density, and differences in stream depth. Fish body condition was significantly positively correlated with water temperature, conductivity, and depth $(\mathrm{P}<0.05)$.

\section{Discussion}

With the exception of the Smolnica, the small lowland streams analysed in this study provide adequate conditions for rearing salmonid juvenile stages. In the Smolnica, described over 50 years ago by Iwaszkiewicz et al. (1964), there was an autochthonous population of brown trout accompanied by bullhead, Cottus gobio L. However, the retention reservoirs constructed in the early twenty-first century caused degradation in the Smolnica that rendered it inhospitable to stenotopic species, which was confirmed in the present study. The environmental parameters of the other six streams differ, which affects the biological parameters of fry. The streams can be grouped firstly by characteristics such as width, depth, the proportion of gravel surfaces, temperature, and conductivity.

The highest fry survival rate was noted in the smallest streams with low water temperatures in spring and summer and low conductivity. Stable conditions, including flow rates, amounts of suspensions, and physicochemical parameters, are more frequently noted in small streams (Louison and Stelzer 2016). Grudniewska et al. (2011) reports the highest fry survival rates in small lowland streams in northern Poland. Water temperature is a basic factor that has a direct impact on the survival, growth, and behavior of salmonid fish; moreover, it limits dissolved oxygen content. Elliot (2015) reports a negative correlation between temperature in the summer and fry growth in streams of northwestern England, whereas Richard et al. (2015) report a positive correlation between these factors in upland streams in Switzerland. Literature data indicate that both sea trout and brown trout stop feeding when water temperatures reach $20^{\circ} \mathrm{C}$, while $24^{\circ} \mathrm{C}$ is considered lethal (Backiel 1964, Alabaster and Lloyd 1982, Crisp 1993, 2000, Elliot and Elliot 2010, Broadmeadow et al. 2011). During the present study, sea trout specimens in the smolt stage were identified in one stream in which aerobic conditions were good and water transparency was high, but the water temperature exceeded $23^{\circ} \mathrm{C}$. These specimens were in excellent condition with no signs of weakness. This suggests that water temperatures ranging from 20 to $24^{\circ} \mathrm{C}$ are not necessarily a factor that limits the growth and survival of older developmental stages of sea trout. Salmonids have higher oxygen demand than do other fish groups, and salmonid fry have higher oxygen demand than do older specimens (Alabaster and Lloyd 1982, Crisp 2000). Conductivity in trout streams typically does not exceed $500 \mu \mathrm{S} \mathrm{cm}^{-1}$. Elevated conductivity indicates an abundance of the mineral forms of nutrients that are leached from the catchment area and enhance stream productivity while simultaneously contributing to deteriorating water quality (Hermanowicz et al. 1999).

The predominance of Gammarus sp., but also the benthic species composition and population density, in the streams investigated is typical of temperate zone lowland streams, while seasonal fluctuations do not indicate changes in ecological status (Kownacki et al. 2002, Pilecka-Rapacz et al. 2011). The most frequent component of the salmonid diet is benthic invertebrates, and streams with high population densities of these organisms provide an appropriate food base for juvenile stages of this group of fishes (Johansen et al. 2010, Pilecka-Rapacz 2011, Czerniawski et al. 2015). The current investigations indicate that the benthic invertebrate population density of approximately 700 ind. $\mathrm{m}^{-1}$ guarantees high fry survival and growth rates. Amundsen et al. (2001) report similar population densities and observed no decreases in these fry parameters.

The mean fry survival rates in the streams analysed, excluding the Smolnica, are very good. When 
stocking with unreared sea trout and salmon fry, the survival rate to the fall fry stage rarely reaches $10 \%$, while survival to the smolt stage does not exceed $2 \%$ (Sych and Bartel 1979). Augustyn (2011) reports survival rates to the fall fry stage released into rivers of southern Poland of $0.2-2.75 \%$ and to the spring fry stage of approximately $1 \%$. In their investigation of fry stages in wild populations of sea trout in Norwegian streams, Kvingedal and Einum (2011) report relatively high, although highly varied, survival to the summer fry stage of $28-79 \%$, at a mean of $48 \%$.

The survival of fry on feed to the fall fry stage in lowland streams of northwestern Poland was three-fold lower than that of unreared fry, and it ranged from 29 to 58\% (Trzebiatowski and Domagała 1992b). Czerniawski et al. (2010a, 2011) reared sea trout fry for periods of four to 10 weeks using artificial feed, zooplankton, nekton, and a mixture of feed and zooplankton. These fry were stocked into streams with a maximum width of $1.5 \mathrm{~m}$, gravel bottoms, and maximum water temperatures of $20^{\circ} \mathrm{C}$. After four weeks of rearing on mixed feed, the survival rate to the fall fry stage was approximately $45 \%$, which is comparable to the results in the present study. Extending the rearing period to 10 weeks did not have a significant impact on the survival rate of fish fed live food in contrast to those fed only artificial feed, in which this index was markedly lower.

The highest mortality rate of fry that were reared traditionally is observed in the first few days after stocking. In this period, fish weight loss and mortality is marked and can be ten-fold higher than in wild fish (Brown and Day 2002, Brockmark and Johnsson 2010, Czerniawski et al. 2011). Borsuk et al. (2006) report there are also two critical periods in the first year of life of wild fish. The first is from 33 to 70 days after leaving the gravel, in which mortality associated with the beginning of exogenous feeding is high. The second period begins in mid or late summer following which the stocking density decreases and mortality starts to decrease. The analysis of the results of the present study indicates that feeding fry natural food earlier and for a short period facilitates avoiding the critical period of high post-stocking mortality, while it also increases considerably survival rates in relation to fry from natural spawning.

The considerable increase in daily mortality observed in the summer coincides with the second critical period that Borsuk et al. (2006) identifies and that could be caused by deteriorating thermal and oxygen conditions in combination with intra-population mechanisms that regulate fry stocking rates. According to the model proposed by Ricker (1954), stocking density is the most important aspect of stocking that impacts the survival of fry in the exogenous feeding stage in the first six months following release, and it must not exceed 5 ind. $\mathrm{m}^{-2}$. The maximum initial stocking density in the present study was 2.2 ind. $\mathrm{m}^{-2}$, which had no significant impact on later survival. Stocking densities proposed by various authors range from 1 ind. $\mathrm{m}^{-2}$ (Chełkowski et al. 1990, Augustyn 2011, Kvingedal and Einum 2011), to 2-3 (Mortensen and Penczak 1985) and up to 9-10 ind. $\mathrm{m}^{-2}$ (Borsuk et al. 2006).

Another critical fry survival parameter is how long they are held in artificial conditions. The longer the fry spend in captivity, the more pronounced the loss of natural instinct is, and the fry become increasingly domesticated (Berejikian et al. 2000, Brown and Day 2002, Teixeira et al. 2006, Brockmark and Johnsson 2010). In the present experiment, the rearing period under controlled conditions was limited to four weeks from yolk sac resorption. The fry were also fed natural food, which facilitated them retaining their natural behavior and developing the skills required to feed in the natural environment of the streams following release.

The lower number of sea trout specimens caught during the fall and spring catches in the following year is obviously caused by downstream migration, which was confirmed by additional catches made downstream from the investigated sections of the streams. Sea trout fry exhibit limited exploratory activity in the first six months. In a study by Jonsson (2001), 96\% of the fish caught during fall fry catches were caught at the stocking site. Kvingedal and Einum (2011) observed limited migrations and non-uniform spatial distribution in sea trout fry aged 
$0+$. In turn, Teixeira et al. (2006) report that $80 \%$ of sea trout specimens aged $1+$ show a strong tendency to migrate as soon as one month after stocking.

The size, body condition, and daily weight gain of fry in different streams and study periods fluctuated substantially depending on environmental conditions. Generally, the highest parameter values were noted in streams with more depth variation, a richer food base, better aerobic conditions, and high water conductivity. Significantly, conductivity was negatively correlated with survival and positively correlated with body condition. The few studies that investigated water conductivity found no correlations with body condition or survival (Dennis et al. 1995, Copp 2003). However, in the experience of the present authors, higher water conductivity indicates increased stream productivity that can lead to oxygen deficits in the summer while also supporting a richer food base. In the summer, body condition and average daily body weight gains decreased considerably, except in the Bąblinek stream, which is consistent with observations reported by Elliot (2015).

Body weight gain reported by other authors in fry from streams in northern and central Poland also fluctuate greatly regardless of the type of food used in rearing (Domagała and Dziewulska 2003, Kirczuk and Domagała 2003, Domagała et al. 2005, Pilecka-Rapacz et al. 2011). Since there is a lack of environmental data in the available literature, it is difficult to determine if there are dependencies among growth rate and survival and habitat conditions. Only Pilecka-Rapacz et al. (2011) state that food availability is not a limiting factor in the length of the fish caught. The increments in body length and weight recorded in the present study were slightly lower in comparison to means from other lowland streams, but body condition was higher. Natural populations of brown trout from Drawa tributaries are characterized by slightly longer body length and heavier weight (Golski et al., unpublished data). The richest ichthyocenoses were observed in transitional and forested sections of streams that, comparatively, provide the least transformed habitats and good environmental conditions (Golski et al. 2010).
The correlations indicate that dissolved oxygen content, and particularly that in summer, is a factor that limits growth in fry since, of all the developmental stages, it is the most sensitive to oxygen deficits. The negative impact of oxygen deficits is manifested not only in fish mortality, but also in the refusals of fish to feed and subsequent growth inhibition. Another parameter that is significantly correlated with fish size is depth variation, which is linked with stream channel morphometry and microhabitat richness. Streams with varied bottom surfaces provide fish with appropriate habitats, fish distribution is more uniform, and the stress stemming from competition for territory is reduced. Studies by Kvingedal and Einum (2011) and Elliot (2015) indicate that spatial variability in fry distribution in the summer influences first fry growth and, to a lesser degree, survival. Höjesjö et al. (2014) report that considerable microhabitat variation has a positive effect on the density, biomass, and condition of young-of-the-year $(0+)$ brown trout. The availability of instream cover has a positive effect on growth potential. Jonsson (2001) reports that brown trout $12 \mathrm{~cm}$ in length defend territories measuring $1 \mathrm{~m}^{2}$.

\section{Conclusions}

- The results of this study indicate that small lowland streams have considerable, potential as rearing sites for juvenile salmonid stages, but that this is largely unexploited. Environmental conditions for fry are optimal and can facilitate high survival and good growth rates.

- No differences in the parameters analyzed were observed between sea trout and brown trout.

- Streams differ in terms of environmental parameters, which is reflected in a certain degree of differentiation in the biological parameters of different fry grades.

- Variability can be exploited when planning stocking and catches. Material reared as summer or fall fry $0+$ or possibly spring fry $1+$ can be caught and transferred to target streams. 
- Limiting fry rearing under controlled conditions to a maximum four weeks and feeding the fry zooplankton improve fry survival. Using zooplankton as food is recommended because of its nutritive value, availability, and active mobility in the limnetic zone, which helps to develop the predatory instincts of the fry.

- Semi-natural fry propagation should be considered in modern models of rational salmonid management because of the low operational costs and the excellent biological parameters of the material that is produced.

Acknowledgments. The study was conducted within the framework of project no. 3541/B/P01/2010/39 financed by the National Science Centre.

Author contributions. J.G. designed the research and methods, performed the research, interpreted the data, wrote the manuscript, searched for literature; J.M. performed the research, reviewed and improved the manuscript; W.A. performed the research, reviewed and improved manuscript, searched for literature; A.P. designed the research; J.K. statistically analyzed the data, interpreted the data.

\section{References}

Alabaster, J.S., Dan R. Lloyd. 1982 - Water Quality Criteria for Freshwater Fish. Second Edition - Food and Agriculture Organization of United Nations, Butterworths, London.

Amundsen P.-A., Gabler H.-M., Riise L.S. 2001 - Intraspecific food resource partitioning in Atlantic salmon (Salmo salar) parr in a subarctic river - Aquat. Living Resour. 14: 257-265.

Augustyn L. 2011 - Optimisation of stocking with brown trout fry - Komun. Ryb. 5: 13-22 (in Polish).

Augustyn L., Bartel R., Epler P. 2006 - Effects of fish size on post-stocking mortality and growth rate of brown trout (Salmo trutta trutta m. fario L.) fry - Acta Sci. Pol., Piscaria 5: 17-28.

Backiel T. 1964 - Trouts - Państwowe Wydawnictwo Rolnicze i Leśne, Warszawa (in Polish).

Bartel R. 1987 - Distribution, migrations and growth of tagged Drawa salmon (Salmo salar L.) - J. Appl. Ichthyol. 3: 33-38.
Bartel R. 2001 - Return of salmon back to Polish waters Ecohydrol. Hydrobiol. 1: 377-392.

Berejikian B.A., Tezak E.P., Flagg T.A., LaRae A.L., Kummerow E., Mahnken C.V.W. 2000 - Social dominance, growth and habitat use of age-0 steelhead (Oncorhynchus mykiss) grown in enriched and conventional hatchery rearing environments - Can. J. Fish. Aquat. Sci. 57: 628-636.

Bębnowska S., Kaczkowski Z., Frankiewicz P., Trojanowska A. 2005 - Potential modification of natural behaviour in farmed fish for stocking of open waters - In: Trout culture in Poland. Past and new problems (Ed.) A. Siwicki, Wyd. IRS, Olsztyn: 75-84 (in Polish).

Borsuk M.E., Reichert P., Peter A., Schager E., Burkhardt-Holm P. 2006 - Assessing the decline of brown trout (Salmo trutta) in Swiss rivers using a Bayesian probability network - Ecol. Model. 192: 224-244.

Broadmeadow S.B., Jones J.G., Langford T.E.L., Shaw P.J., Nisbet T.R. 2011 - The influence of riparian shade on lowland stream water temperatures in southern England and their viability for brown trout - River Res. Appl. 27: 226-237.

Brockmark S., Johnsson J.I. 2010 - Reduced hatchery rearing density increases social dominance, postrelease growth and survival in brown trout (Salmo trutta) - Can. J. Fish. Aquat. Sci. 67: 288-295.

Brown C., Day R. L. 2002 - The future of stock enhancements: lessons for hatchery practice from conservation biology Fish Fish. 3: 79-94.

Chełkowski Z., Filipiak J., Trzebiatowski R., Ciupiński M. 1990 - Determination of population size for trout (Salmo trutta L.) fry in stocking of watercourses in the Grabowa catchment - Instrukcja wdrożeniowa 2/90, Akademia Rolnicza w Szczecinie (in Polish).

Copp G.H. 2003 - Is fish condition correlated with water conductivity? - J. Fish Biol. 63: 263-266.

Crisp D.T. 1993 - The environmental requirements of salmon and trout in fresh water - Freshw. Forum 3: 176-202.

Crisp D.T. 2000 - Trout and Salmon: Ecology, Conservation and Rehabilitation - Fishing News Books, Blackwell Science.

Czerniawski R., Czerniejewski P. 2007 - Rearing sea trout (Salmo trutta m. trutta L., 1758) fry for stocking fed on zooplankton caught in the outlets of natural and artificial bodies of water - Acta Sci. Pol., Piscaria 6: 15-30.

Czerniawski R., Domagała J., Pilecka-Rapacz 2009a - Preliminary results of studies on feeding the sea trout (Salmo trutta m. trutta L.) with live zooplankton and larvae of chironomids (Chironomidae) on its survival and growth in watercourses - Zeszyty Naukowe Uniwersytetu Szczecińskiego, Acta Biol. 16: 17-29 (in Polish).

Czerniawski R., Domagała J., Pilecka-Rapacz M. 2009b Rearing of sea trout fry (Salmo trutta trutta L.) - as potential 
stocking material, with living zooplankton and dry prepared food - EJPAU, 12(4) \#14, http://www.ejpau.media.pl /volume12/issue4/art-14.html.

Czerniawski R., Domagała J., Pilecka-Rapacz M. 2010a Growth and survival of brown trout fry (Salmo trutta m. fario L.) in the wild, reared in the hatchery on different feed - EJPAU 13(2), \#04, http://www.ejpau.media.pl /volume13/issue2/art-04.html.

Czerniawski R., Domagała J., Pilecka-Rapacz M. 2010b - The effect of rearing trout fry (Salmo trutta m. trutta) on live zooplankton on their survival and growth in natural conditions - preliminary results - Rocz. Nauk. PZW 23: 131-139 (in Polish).

Czerniawski R., Pilecka-Rapacz M., Domagala J. 2011 Stocking experiment with Atlantic salmon and sea trout parr reared on either live prey or a pellet diet - J. Appl. Ichthyol. 27: 984-989.

Czerniawski R., Pilecka-Rapacz M., Domagała J., Sługocki Ł. 2012 - Rearing of larvae of sea trout and Atlantic salmon on pellet, zooplankton and nekton diets - Rocz. Nauk. PZW 25: 73-84 (in Polish).

Czerniawski R., Domagała J., Krepski T., Pilecka-Rapacz M. 2015 - Impact of live food on survival and growth of hatchery-reared sea trout (Salmo trutta trutta L.) parr in the wild - J. Appl. Ichthyol. 31: 95-99.

Dennis T.E., MacAvoy S.E., Steg M.B., Bulger A.J. 1995 - The association of water chemistry variables and fish conditions in streams of Shenandoah National Park (USA) Water Air Soil Pollut. 85: 365-370 (in Polish).

Domagała J., Dziewulska K. 2003 - Gonadal development of one-year-old alevins of the sea trout (Salmo trutta m. trutta) - Zeszyty Naukowe Uniwersytetu Szczecińskiego, Acta Biol. 10: 83-93.

Domagała J., Pilecka-Rapacz M., Poleszczuk G. 2005 - The growth rate, body condition and weight of the alimentary canal of sea trout (Salmo trutta m. trutta) fry in the Smerdnica stream. Preliminary results - Zeszyty Naukowe Uniwersytetu Szczecińskiego, Acta Biol. 12: 27-34 (in Polish).

Elliott J.M., Elliott J.A. 2010 - Temperature requirements of Atlantic salmon Salmo salar, brown trout Salmo trutta and Arctic charr Salvelinus alpinus: predicting the effects of climate change - J. Fish Biol. 77: 1793-1817.

Elliot J.M. 2015 - Density - dependent and density - independent growth in a population of juvenile sea - trout, Salmo trutta, assessed using long-term data from a small stream in Northwest England - Freshw. Biol. 60: 336-346.

Golski J., Przybył A., Mazurkiewicz J., Andrzejewski W., Trawiński J. 2010 - Habitat variability and fish species structure in Kończak stream - Oceanol. Hydrobiol. Stud. 39: 83-98.

Grudniewska J., Goryczko K., Witkowski A., Kozłowski J., Stańczak K., Kozłowski K., Gęsiarz G., Stabiński R. 2011
- Effects of stocking brown trout, Salmo trutta m. fario L., into rivers in Kashubian Pomerania and Suwałki Komun. Ryb. 2: 1-6 (in Polish).

Hermanowicz W., Dojlido J., Dożańska W., Koziorowski B., Zerbe J., 1999 - Physico-chemical analyses of water and sewage - Arkady, Warszawa, 555 p. (in Polish).

Höjesjö J., Gunve E., Bohlin T., Johnsson J.I. 2014 - Addition of structural complexity - contrasting effect on juvenile brown trout in a natural stream - Ecol. Freshw. Fish 24: 608-615.

Iwaszkiewicz M. 1965 - Biogenic characteristics of lowland streams as the basis for their management - Rocz. WSR w Poznaniu XXIV: 73-107 (in Polish).

Iwaszkiewicz M., Kaj J., Włoszczyński B. 1964 - A determination of fishery efficiency of the lower course of the Wełna River - Rocz. WSR w Poznaniu, XXII: 69-79 (in Polish).

Jonsson S. 2001 - Stocking of Brown Trout (Salmo trutta L.): Factors affecting survival and growth - Acta Universitstis Agriculturae Sueciae, Silvestria 230, Doctoral thesis, Swedish University of Agricultural Sciences.

Johansen M., Thorstad E.B., Rikardsen A.H., Koksvik J.I., Ugedal O., Jensen A.J., Saksgard L., Naesje T.F. 2010 Prey availability and juvenile Atlantic salmon feeding during winter in a regulated subarctic river subject to loss of ice cover - Hydrobiologia 644: 217-229.

Kaj J. 1946 - Stocking the Warta basin with trout - Prz. Ryb. XIII, 3 (in Polish).

Kirczuk L., Domagała J. 2003 - Characteristics of young sea trout (Salmo trutta m. trutta) growing in Pomeranian rivers to the smolt stage - EJPAU, 6(1), \#03, http://www.ejpau.media.pl/volume6/issue1/fisheries/art-03.html.

Kownacki A., Soszka H., Fleituch T., Kudelska D. 2002 - The ecological assessment of river quality in Poland on the basis of communities of benthic invertebrates - In: River biomonitoring and benthic invertebrate communities (Eds) A. Kownacki, H. Soszka, T. Flaituch, D. Kudelska, Szafer Institute of Botany, Polish Academy of Sciences, Warszawa-Kraków: 71-88 (in Polish).

Kvingedal E., Einum S. 2011 - Intracohort and intercohort spatial density dependence in juvenile brown trout (Salmo trutta) - Can. J. Fish. Aquat. Sci. 68: 115-121.

Louison M. J., Stelzer R., S. 2016 - Use of first-order tributaries by brown trout (Salmo trutta) as nursery habitat in a cold water stream network - Ecol. Freshw. Fish 25: 133-140.

Mortensen E., Penczak T. 1985 - Stocking lowland streams with the brown trout - Gosp. Ryb. 7-8: 29-31 (in Polish).

Pilecka-Rapacz M., Domagała J., Czerniawski R. 2011 - Diet of sea trout (Salmo trutta trutta) parr in relation to food resources in three small forest streams - Rocz. Nauk. PZW 24: 133-146 (in Polish). 
Przybył A. 1976 - Protection of salmonid fish in the Warta basin during the Great Poznań Duchy - Gosp. Ryb. 14-16 (in Polish).

Ricker W.E., 1954 - Stock and recruitment - J. Fish. Res. Bd. Can. 11: 559-623.

Richard A., Cattaneo F., Rubin J.-F. 2015 - Biotic and abiotic regulation of a low-density stream-dwelling brown trout (Salmo trutta L.) population: effects on juvenile survival and growth - Ecol. Freshw. Fish 24: 1-14.

Sych R., Bartel R., 1979 - Program for development of salmon culture - MIR, Gdynia (in Polish).
Teixeira A., Cortes R.M.V., Oliveira D. 2006 - Habitat use by native and stocked trout (Salmo trutta L.) in two northeast streams, Portugal - Bull. Fr. Peche Piscic. 382: 1-18.

Trzebiatowski R., Domagała J. 1992a - Potential increase in effectiveness of stocking watercourses with trout (Salmo trutta L.) hatch. I. Egg incubation and hatch rearing Zesz. Nauk. AR Wroc. Zoot. XXXVII 218: 35-40 (in Polish).

Trzebiatowski R., Domagała J. 1992b - Potential increase in effectiveness of stocking watercourses with trout (Salmo trutta L.) hatchlings. II. Survival of advanced and free-swimming hatch introduced to watercourses - Zesz. Nauk. AR Wroc. Zoot XXVII 218: 41-44 (in Polish). 